\title{
ANALISIS KINERJA PEMERINTAH DAERAH KABUPATEN KAMPAR TAHUN 2013
}

\author{
Aras Aira, SE, M.Ak \\ Dosen Fakultas Ekonomi dan Ilmu Sosial \\ Universitas Islam Negeri Sultan Syarif Kasim Riau
}

\begin{abstract}
Abstrak
Konsekuensi dari diberlakukannya otonomi daerah, membuat daeeah memiliki hak dan wewenang dalam menyelenggarakan dan mengelola pemerintahan daerah, untuk itu daerah harus mampu menunjukkan apa yang dicapainya dengan menunjukkan dengan kinerja daerah yang bagus sesuai dengan apa yang dibutuhkan masyarakat, memberikan pelayanan yang berkualitas kepada masyarakat, dan mampu mempertanggungjawabkan kinerja yang telah ditelah dilaksanakan kepada public. Kinerja diartikan sebagai konsep kinerja merupakan singkatkan kinetika energy kerja yang padanannya dalam bahasa inggris adalah performance. Istilah performance ini sering di indonesiakan sebagai performa. Kinerja adalah keluaran yang dihasilkan oleh fungsi-fungsi atau indicator-indikator suatu pekerjaan atau suatu profesi dalam waktu tertentu. Kabupaten Kampar adalah salah satu kabupaten di Provinsi Riau, yang melaporkan kinerjanya dengan LAKIP (Laporan Kinerja Pemerintah). Dari LAKIP yang dibuat dapat dilihat masih adanya kekurangan-kekurangan dalam mengukur indikator kinerja, masih terdapatnya indikator kinerja yang masih belum bisa diukur dengan alasan tidak adanya data yang memadai untuk pertanggungjawaban, masih adanya beberapa bidang yang memilki pencapaian kinerja tidak mencapai $100 \%$, dan masih terdapat kesalahan dalam membuat LAKIP.
\end{abstract}

Kata Kunci : Pemerintah daerah, Kinerja, LAKIP

\section{PENDahuluan}

Otonomi daerah diberlakukan di Indonesia melalui Undang-Undang Nomor 22 Tahun 1999 tentang Pemerintahan Daerah (Lembaran Negara Republik Indonesia Tahun 1999 Nomor 60, Tambahan Lembaran Negara Republik Indonesia Nomor 3839). Pada tahun 2004, Undang-Undang Nomor 22 Tahun 1999 tentang Pemerintahan Daerah dianggap tidak sesuai lagi dengan perkembangan keadaan, ketatanegaraan, dan tuntutan penyelenggaraan otonomi daerah ${ }^{1}$ sehingga digantikan dengan Undang-Undang Nomor 32 Tahun 2004 tentang Pemerintahan Daerah (Lembaran Negara Republik Indonesia Tahun 2004 Nomor 125,
Tambahan Lembaran Negara Republik Indonesia Nomor 4437). Selanjutnya, Undang-Undang Nomor 32 Tahun 2004 tentang Pemerintahan Daerah hingga saat ini telah mengalami beberapa kali perubahan, terakhir kali dengan Undang-Undang Nomor 12 Tahun 2008 tentang Perubahan Kedua atas Undang-Undang Nomor 32 Tahun 2004 tentang Pemerintahan Daerah (Lembaran Negara Republik Indonesia Tahun 2008 Nomor 59, Tambahan Lembaran Negara Republik Indonesia Nomor 4844)..

Ini merupakan kesempatan yang sangat baik bagi pemerintah daerah untuk membuktikan kemampuannya dalam melaksanakan kewenangan yang menjadi hak 
daerah. Maju atau tidaknya suatu daerah sangat ditentukan oleh kemampuan dan kemauan untuk melaksanakan yaitu pemerintah daerah. Pemerintah daerah bebas berkreasi dan berekspresi dalam rangka membangun daerahnya, tentu saja dengan tidak melanggar ketentuan hukum yaitu perundang-undangan

Konsekuensi logis adanya otonomi daerah membuat pemerintahan daerah harus memiliki tanggung jawab yang lebih besar dari pada sebelumnya, otonomi daerah adalah hak, wewenang, dan kewajiban daerah otonom untuk mengatur dan mengurus sendiri urusan pemerintahan dan kepentingan masyarakat setempat sesuai dengan peraturan perundang-undangan. Secara harfiah, otonomi daerah berasal dari kata otonomi dan daerah. Dalam bahasa Yunani, otonomi berasal dari kata autos dan namos. Autos berarti sendiri dan namos berarti aturan atau undang-undang, sehingga dapat dikatakan sebagai kewenangan untuk mengatur sendiri atau kewenangan untuk membuat aturan guna mengurus rumah tangga sendiri. Sedangkan daerah adalah kesatuan masyarakat hukum yang mempunyai batas-batas wilayah.Pelaksanaan otonomi daerah selain berlandaskan pada acuan hukum, juga sebagai implementasi tuntutan globalisasi yang harus diberdayakan dengan cara memberikan daerah kewenangan yang lebih luas, lebih nyata dan bertanggung jawab, terutama dalam mengatur, memanfaatkan dan menggali sumber-sumber potensi yang ada di daerahnya masing-masing.

Selain menimbulkan hak, wewenang dan kewajiban otonomi daerah memilki banyak manfaat untuk pemerintahan daerah, terutama untuk kesejahteraan rakyat. Walaupun demikian dalam otonomi daerah, daerah tidak dileapaskan begitu saja dalam melaksanakan pemerintahan daerah tanpa ada bentuk pertanggungjawaban dari pemerintahan daerah. Pemerintahan daerah harus melaporkan kinerja pemerintahan daerah sebagai bentuk bahwa daerah telah bertanggungjawab dan berupaya dalam penyelenggaran dan pengelolaan daerah sesuai yang diamanatkan. Kinerja diartikan hasil kerja secara kualitas dan kuantitas yang dicapai oleh pemerintahan daerah dalam melaksanakan tugasnya sesuai tanggung jawab yang diberikan kepadanya.

Visi-misi pemerintahan daerah ditujukan untuk memastikan bahwa masyarakat memperoleh pelayanan yang baik dan layak dari daerah dan masyarakat merasa puas atas infrastruktur yang diberikan oleh pemerintah, tingkat kesehatan yang membaik, dan meningkantnya anak-anak usia sekolah yang berada pada bangku sekolah. Untuk itu penialaian terhadap kinerja yang dicapai oleh daerah semakin penting untuk memastikan bahwa terlindunginya kepentingan masyarakat dan visi misi tercapai.

Dengan demikian kinerja dalam pengukurannya harus diukur dengan indicator yang benar-benar relaevan dalam penilaian kinerja dengan tujuan agar pelaporan kinerja yang dilaoprkan daerah benar-benar menggambarkan keadaan sebenarnya sehingga masyarakat percaya akan kemampuan daerah dalam bekerja untuk kepentingan masyarakat banyak bukan golongan tertentu saja.

Kabupaten Kampar dibentuk berdasarkan undang-undang no 12 tahun 1956 tentang pembentukan daerah otonomi kabapaten dalam lingkungan daerah provinsi Sumatra tengah, dengan terbentuknya provinsi riau berdasarkan undang-undang darurat no 19 tahun 1957 kemudian diundang-undangkan dengan undang-undang no 61 tahun 1958, kabupaten Kampar merupakan salah satu daerah yang termasuk dalam provinsi Riau. Sejalan dengan era reformasi tahun 1998 kabupaten Kampar dimekarkan menjadi 3 kabupaten yaitu kabupaten Kampar dengan ibukota Bangkinang,kabupaten Pelalawan dengan ibukota Pangkalan kerinci dan kabupaten 
Rokan Hulu dengan ibukota Pasir Pengaraian.

Berdasarkan undang-undang no 32 tahun 2004 tentang pemerintahan daerah, pemerintah daerah Kabupaten Kampar diberi kewenanagan mengatur dan megurus sendiri urusan pemerintahan dan kepentingan masyarakat setempat menurut prakarsa sendiri berdasarkan aspirasi masyarakat sesuai dengan peraturan perundangundangan. Sehingga dalam penyelenggaraan pemerintah daerah kabupaten Kampar memeperoleh hak, kewenangan dan tanggung jawab sendiri dalam menyelenggarakan dan mengelola pemerintah daerah, untuk itu pemerintah daerah yang berhasil adalah pemerintah daerah yang mampu memiliki kinerja yang baik.

\section{PEMbahaSAN}

\section{Pengertian Pemerintah Daerah}

Pemerintah daerah merupakan subsistem dari Negara Kesatuan Republik Indonesia, untuk itu maka tugas-tugas negara/pemerintah merupakan tugas-tugas pemerintah daerah juga namun tidak semua tugas-tugas ataupun urusan-urusan pemerintahan diserahkan kepada daerah dengan pertimbangan keadaan dan kemampuan daerah serta kepentingan nasional. Dalam praktek penyelenggaraan pemerintahan dan masyarakat sebagai pihak yang diperintah seyogyanya berada pada posisi yang seimbang.

Pemerintah merupakan suatu organisasi yang mempunyai tujuan dalam melaksanakan tugas dan fungsinya sebagai pelayan masyarakat. Kemampuan aparatur yang ada di lembaga pemerintah sangat penting arti dan keberadaannya dalam rangka meningkatkan mutu pelayanan kepada publik. Sarana dan prasarana yang lengkap tanpa ditunjang dengan kemampuan Sumber Daya Manusia (SDM) yang berkualitas, maka lembaga tersebut sulit untuk maju dan berkembang.
Pengembangan kemampuan SDM pada hakekatnya adalah dalam rangka meningkatkan kemampuan sehingga dapat dicapai efektivitas pelayanan pemerintah kepada masyarakat berdasarkan ukuran dan target yang diharapkan. Desentralisasi telah melahirkan adanya otonomi daerah. Dengan lahirnya otonomi daerah, setiap daerah dibagi kedalam beberapa wilayah yang meliputi wilayah provinsi, kabupaten dan kota.

Peran pemerintah daerah sangat penting dalam menciptakan iklim pemerintahan daerah yang lebih maju dan mampu menghasilkan pembangunan yang merata, luas dan bertanggung jawab. Pada era otonomi setiap daerah harus berusaha menggali potensi yang dimiliki daerah. sebagaimana yang diamanatkan dalam undang-undang no 32 tahun 2004 tentang penyelenggaran pemerintahan daerah. undang-undang no 32 tahun 2004 mengisyaratkan bagi setiap daerah untuk bekerja lebih. Dalam mewujudkan pemerintahan daerah yang lebih efisien dan efektif setra memperhatikan aspek-aspek hubungan antara susunan pemerintahan dan antar pemerintahan daerah agar tercipta kondisi yang harmonis antar pemerintahan.

Dalam penyelenggaraan pemerintahan di daerah adalah selaras dengan azas desentralisasi, dekonsentrasi, dan tugas pembantuan dapat diwujudkan dalam fungsifungsi pemerintah daerah. Adapun fungsi pemerintah daerah menurut Misdyanti dan R.G. Kartasapoetra adalah:

1. Fungsi otonomi

Fungsi otonomi dari pemerintah daerah adalah melaksanakan segala urusan yang telah diserahkan oleh pemerintah pusat maupun daerah yang lebih tinggi tingkatannya.

2. Fungsi pembantuan

Merupakan fungsi untuk turut serta dalam melaksanakan urusan pemerintahan yang ditugaskan kepada pemerintah daerah oleh pusat atau pemerintah daerah tingkat 
atasnya dengan kewajiban mempertanggung jawabkan kepada yang menugaskannya.

3. Fungsi Pembangunan

Fungsi ini untuk meningkatkan laju pembangunan dan menambah kemajuan masyarakat sehingga tuntutan dari masyarakatpun semakin berkembang dan kompleks

4. Fungsi lainnya

Selain ketiga fungsi diatas terdapat fungsi lainnya adalah:

a) Pembinaan wilayah

b) Pembinaan masyarakat

c) Pemberian pelayanan,pemeliharaan serta perlindungan kepentingan umum. ( Misdyanti dan Kartasapoetra, 1993: 20-27).

Fungsi pemerintah daerah diatas dapat dikatakan bahwa pembinaan wilayah adalah upaya dari pemerintah daerah untuk meningkatkan sumber daya wilayah yang masih tertinggal, dimana wilayah-wilayah tersebut dapat diupayakan untuk meningkatkan sumber daya yang dimilikinya demi meningkatkan wilayahnya.

Adapun upaya pemerintah daerah mengenai pembinaan masyarakat adalah salah satu upaya dari pemerintah daerah untuk meningkatkan sumber daya manusia yang ada dalam suatu wilayah agar lebih mandiri dan berkualitas demi kesejahteraan keluarga dan masyarakat.

Selain fungsi pembinaan wilayah dan pembinaan masyarakat diatas maka fungsi lain dari pemerintah adalah pemberian pelayanan, pemeliharaan serta perlindungan kepentingan umum merupakan salah satu fungsi pemerintah sebagai birokrasi dalam memberikan pelayanan kepada masyarakat yang membutuhkan pelayanan dari pemerintah karena fungsi dari pemerintah itu sendiri adalah memberikan pelayanan misalnya pelayanan pembuatan Kartu Tanda Penduduk (KTP) dan perlindungan kepentingan umum bagi masyarakat lemah yang ditindas oleh kaum penguasa.

\section{Kinerja}

Pengembangan evaluasi kinerja perlu dilakukan dengan hati-hati karena akan menentukan kinerja aparatur negaradan kinerja organisasi. Wirawan (2009) menyebutkan bahwa kinerja adalah konsep kinerja merupakan singkatkan kinetika energy kerja yang padanannya dalam bahasa inggris adalah performance. Istilah performance ini sering di indonesiakan sebagai performa. Kinerja adalah keluaran yang dihasilkan oleh fungsi-fungsi atau indicator-indikator suatu pekerjaan atau suatu profesi dalam waktu tertentu. Berbeda dengan Bernardin dan Russel (1993 : 379) dalam Yeremias T. Keban (2004 : 192) mengartikan kinerja sebagai the record of outcomes produced on a specified job function or activity during a specified time period. Dalam definisi ini, aspek yang ditekankan oleh kedua pengarang tersebut adalah catatan tentang outcome atau hasil akhir yang diperoleh setelah suatu pekerjaan atau aktivitas dijalankan selama kurun waktu tertentu. Dengan demikian kinerja hanya mengacu pada serangkaian hasil yang diperoleh seorang pegawai selama periode tertentu dan tidak termasuk karakteristik pribadi pegawai yang dinilai.

\section{Faktor - Faktor Yang Mempengaruhi Kinerja}

Kinerja merupakan suatu capaian atau hasil kerja dalam kegiatan atau aktivitas atau program yang telah direncanakan sebelumnya guna mencapai tujuan serta sasaran yang telah ditetapkan oleh suatu organisasi dan dilaksanakan dalam jangka waktu tertentu yang dipengaruhi oleh beberapa faktor. Dalam Yeremias T. Keban (2004 : 203) untuk melakukan kajian secara lebih mendalam tentang faktor-faktor yang mempengaruhi efektivitas penilaian kinerja di 
Indonesia, maka perlu melihat beberapa faktor penting sebagai berikut :

1. Kejelasan tuntutan hukum atau peraturan perundangan untuk melakukan penilaian secara benar dan tepat. Dalam kenyataannya, orang menilai secara subyektif dan penuh dengan bias tetapi tidak ada suatu aturan hukum yang mengatur atau mengendaikan perbuatan tersebut.

2. Manajemen sumber daya manusia yang berlaku memiliki fungsi dan proses yang sangat menentukan efektivitas penilaian kinerja. Aturan main menyangkut siapa yang harus menilai, kapan menilai, kriteria apa yang digunakan dalam sistem penilaian kinerja sebenarnya diatur dalam manajemen sumber daya manusia tersebut. Dengan demikian manajemen sumber daya manusia juga merupakan kunci utama keberhasilan sistem penilaian kinerja.

3. Kesesuaian antara paradigma yang dianut oleh manajemen suatu organisasi dengan tujuan penilaian kinerja. Apabila paradigma yang dianut masih berorientasi pada manajemen klasik, maka penilaian selalu bias kepada pengukuran tabiat atau karakter pihak yang dinilai, sehingga prestasi yang seharusnya menjadi fokus utama kurang diperhatikan.

4. Komitmen para pemimpin atau manajer organisasi public terhadap pentingnya penilaian suatu kinerja. Bila mereka selalu memberikan komitmen yang tinggi terhadap efektivitas penilaian kinerja, maka para penilai yang ada dibawah otoritasnya akan selalu berusaha melakukakan penilaian secara tepat dan benar.

Selanjutnya Yuwono dkk. dalam Hessel Nogi (2005 : 180) mengemukakan bahwa faktor-faktor yang dominan mempengaruhi kinerja suatu organisasi meliputi upaya manajemen dalam menerjemahkan dan menyelaraskan tujuan organisasi, budaya organisasi, kualitas sumber daya manusia yang dimiliki organisasi dan kepemimpinan yang efektif. Banyak faktor yang mempengaruhi kinerja organisasi baik publik maupun swasta.

\section{Penilaian Kinerja}

Menurut Larry D. Stout dalam Hessel Nogi (2005 : 174) mengemukakan bahwa pengukuran atau penilaian kinerja organisasi merupakan proses mencatat dan mengukur pencapaian pelaksanaan kegiatan dalam arah pencapaian misi (mission accomplishment) melalui hasil yang ditampilkan berupa produk, jasa ataupun suatu proses. Berbeda dengan pernyataan yang dikemukakan oleh Bastian (2001 : 330) dalam Hessel Nogi (2005 : 173) bahwa pengukuran dan pemanfaatan penilaian kinerja akan mendorong pencapaian tujuan organisasi dan akan memberikan umpan balik untuk upaya perbaikan secara terus menerus.

Begitu pentingnya penilaian kinerja bagi keberlangsungan organisasi dalam mencapai tujuan, maka perlu adanya indikator-indikator pengukuran kinerja yang dipakai secara tepat dalam organisasi tertentu. Menurut Agus Dwiyanto (2006 : 49) penilaian kinerja birokrasi publik tidak cukup dilakukan dengan menggunakan indikator yang melekat pada birokrasi itu, seperti efisiensi dan efektivitas, tetapi juga harus dilihat dari indikator-indikator yang melekat pada pengguna jasa, seperti kepuasan pengguna jasa, akuntabilitas dan responsivitas. Penilaian kinerja dari sisi pengguna jasa menjadi sangat penting karena birokrasi publik juga muncul karena tujuan dan misi birokrasi public seringkali bukan hanya memiliki stakeholder yang banyak dan memiliki kepentingan yang sering berbenturan satu sama lainya menyebabkan birokrasi publik mengalami kesulitan untuk merumuskan misi yang jelas. Akibatnya, ukuran kinerja organisasi publik di mata para stakeholder juga berbeda-beda. 


\section{Indikator Kinerja}

McDonald dan Lawton dalam Ratminto dan Atik Septi Winarsih (2005:174) mengemukakan indikator kinerja antara lain :output oriented measures throughput, efficiency, effectiveness.Selanjutnya indikator tersebut dijelaskan sebagai berikut :

1. Efficiency atau efisiensi adalah suatu keadaan yangmenunjukkan tercapainya perbandingan terbaik antara masukan dan keluaran dalam penyelenggaraan pelayananpublik.

2. Effectiveness atau efektivitas adalah tercapainya tujuan yang telah ditetapkan, baik dalam bentuk target, sasaran jangka panjang maupun misi organsiasi.

Lenvinne dalam Ratminto dan Atik Septi Winarsih (2005:175) mengemukakan indikator kinerja terdiri dari : responsiveness, responsibility, accountability.

1. Responsiveness atau responsivitas ini mengukur daya tanggap provider terhadap harapan, keinginan, aspirasi serta tuntutan customers.

2. Responsibility atau responsibilitas adalah suatu ukuran yang menunjukkan seberapa jauh proses pemberian pelayanan publik dilakukan dengan tidak melanggar ketentuan-ketentuan yang telah ditetapkan.

3. Accountability atau akuntabilitas adalah suatu ukuran yang menunjukkan seberapa besar tingkat kesesuaian antara penyelenggaraan pelayanan dengan ukuran-ukuran eksternal yang ada di masyarakat dan dimiliki oleh stake holders, seperti nilai dan norma yang berkembang dalam masyarakat.

Zeithaml, Parasuraman dan Berry dalam Ratminto dan Atik epti Winarsih (2005:175) menjelaskan tentang indikator yang digunakan untuk menilai kinerja organisasi, yang terdiri atas beberapa faktor berikut :

1. Tangibles atau ketampakan fisik, artinya ketampakan fisik dari gedung, peralatan, pegawai, dan fasilitas-fasilitas lain yang dimiliki oleh providers.

2. Reliability atau reabilitas adalah kemampuan untuk menyelenggarakan pelayanan yang dijanjikan secara akurat.

3. Responsiveness atau responsivitas adalah kerelaan untuk menolong customers dan menyelenggarakan pelayanan secara ikhlas.

4. Assurance atau kepastian adalah pengetahuan dan kesopanan para pekerja dan kemampuan mereka dalam memberikan kepercayaan kepada customers.

5. Emphaty adalah perlakuan atau perhatian pribadi yang diberikan oleh providers kepada customers.

\section{Pencapaian Kinerja}

\subsection{Di Bidang Peningkatan Akhlak Dan} Moral

Pemerintah daerah kabupaten Kampar bersama DPRD Kampar telah menetapkan Peraturan daerah tentang maghrib mengaji dan membangun sarana dan prasarana ibadah, pemberian bantuan terhadap rumah ibadah dan melaksanakan sholat subuh berjemaah dan safari pembangunan dari desa ke desa se kabupaten Kampar. Sasaran yang dicapai pada bidang peningkatan akhlak dan moral yang terdapat pada LAKIP pemerintah daerah Kabupaten Kampar adalah sebagai berikut :

1. Menigkatnya Fungsi Dan Peran Agama Dalam Masyarakat. Sasaran ini memiliki 10 indikator kinerja, rata-rata pencapain kinerja dibidang ini dengan sasaran meningkatnya fungsi peran agama dan masyarakat rata-rata $87,10 \%$.

2. Meningkatnya Peran Keagamaan Dalam Pembangunan. Sasaran ini menggunakan 3 indikator kinerja yaitu diukur dari jumlah dai dan pemuka agama, jumlah lembaga keagamaan dalam pembinaan, dan persentase kerukunan hidup antar umar beragama, rata-rata pencapaian sasaran 106,67 \%. Ini bearrti bahwa peran 
agama begitu kuat dalam penciptaan kondisi yang rukun dan nyaman, sehingga pembangunan daerah bisa berjalan lancar.

\subsection{Dibidang Pendidikan}

Angka melek huruf merupakan persentase penduduk usia 15 tahun ke atas yang dapat membaca huruf latin dan huruf lainnya. Dengan memiliki kemampuan membaca dan menulis seseorang dapat mengakes informasi lebih luas sehingga yang mempunyai pengetahuan yang cukup dalam meningkatkan kesejahteraannya, dalam hal ini pemerintah daerah telah berhasil dalam meningkatkan angka melek huruf dikabupaten Kampar, ini terlihat dari persentase penduduk yang melek huruf meningkat dari tahun 2012 , pada tahun 2013 angka melek huruf 98,44 \%. Sasaran yang digunakan dalam bidang pendidikan adalah sebagai berikut :

1. Meningkatnya aksebilitas dan pemerataan kesehatan bagi masyarakat miskin. Sasaran ini diukur dengan menggunakan 8 indikator kinerja yaitu : angka melek huruf umur 15-24 tahun, angka partisipasi kasar, angka partisipasi murni, angka pendidikan yang ditamtkan, nilai NEM rata-rata,angka putus sekolah,angka ratarata lama sekolah, angka partisipasi sekolah. Hasil pencapaian pada sasaran ini menunjukkan capaian rata-rata 82,73 $\%$, hal ini diakibatka karena angka partisipasi sekolah pada tingkat SMA masih berada pada 53\% dari target yang ditetapkan $100 \%$.

2. Meningkatnya Mutu Pendidik, Tenaga Pendidik Dan Manajemen Sekolah. Sasaran ini diukur dengan menggunakan 10 indikator kinerja, yaitu jumlah sekolah bersertifikat, jumlah SSN,jumlah RSBI, jumlah SBI, rasio ruang kelas dengan jumlah kelas,rasio guru dengan rata-rata murid, rasio ketersediaan sekolah dengan jumlah anak usia sekolah, rasio guru dan murid, persentase guru bersertifikasi, rasio guru berkualifikasi.jumlah rata-rata pencapaian kinerja adalah 83,56 \%, hal ini disebabkan masih adanya indicator kinerja yang belum bisa dicapai sama sekali yaitu jumlah RSBI dan jumlah SBI yang msih $0 \%$.

3. meningkatnya minat dan budaya gemar membaca masyarakat serta layanan kepustakaan. Sasaran ini diukur dengan 5 indikator kinerja yaitu indeks kepuasan membaca, jumlah perpustakaan public, jumlah

keperpustakaan,jumlah pengelola perpustakaan sekolah dan jumlah pnjaman koleksi pustaka. Hasil pencapaian kinerja menunjukkan masih sedkitnya jumlah pengunjung dan jumlah pinjaman koleksi perpustakaan mengakibatkan rata-rata pencapaian sasaran ini hanya $63,74 \%$.

\subsection{Dibidang Kesehatan}

Pemerintahan daerah Kampar telah melakukan program baik yang bersifat preventif, promotif maupun kuratif, namun masih terlihat kekurangan dalam kesehatan yaitu belum maksimalnya pemberian pelayanan kesehatan karena masih terbatasnya pada infrastruktur daerah, fasilitas daerah. Salah satunya adalah akses atau jalan yang tidak mendukung penduduk untuk merasakan pelayanan kesehatan daerah, selain itu juga dipengaruhi oleh pendapatan masyarakat daerah dan kualitas pelayanan daerah yang diberikan. Seharusnya hal ini lebih bisa dimaksimalkan karena mengingat masyarakat harus mendapatkan pelayanan dari pemerintah dalam kondisi apapun dan dengan jarak yang sejauh apapun karena disanalah letak fungsi pemerintah daerah untuk memastikan masyarakat daerahnya hidup dengan layak dan mendapatkan pelayanan kesehatan yang layak. Pemrintah darah yang berhasil adalah pemerintah daerah yang mampu memberikan hal-hal tersebut kepada rakyatnya. Indicator kinerja sasaran yang digunakan adalah : 
1. Meningkatnya Pelayanan Kesehatan Masyarakat, menggunakan 24 indikator kinerja, yang rata-rata pencapaian kinerja adalah $74,32 \%$. Sedangkan yang terendah adalah pelayanan kesehatan kemitraan RSUD bangkinang dan kualitas pelayanan transfusi darah pada RSUD bangkinang.

2. Meningkatnya Derajat Kesehatan Masyarakat, dengan rata-rata pencapaian kinerja $84.45 \%$, dengan menggunakan 39 indikator kinerja.

3. Meningkatnya Infrastruktur Kesehatan, menggunakan 6 indikator kinerja dangan rata-rata pencapain kinerja $94.86 \%$.

4. Meningkatnya Jumlah Rumah Dan Lingkungan Sehat, dengan menggunkan 4 indikator kinerja dengan pencapaian ratarata kinerja 95,30\%.

5. Meningkatnya Penduduk Yang Memiliki Jaminan Kesehatan. Ini diukur dengan menggunakan 5 indikator kinerja dengan pencapaian $100 \%$.

6. Meningkantnya Pola Hidup Bersih Dan Sehat. Sasaran ini diukur dengan menggunakan 7 indikator denangan tingkat pencapaian rata-rata kinerja $96.85 \%$.

7. Meningkatnya Peran Swasta Dalam Kesehatan. Diukur dengan 5 indikator kinerja, yang rata-rataa pencapain kinerja adalah $100 \%$.

\subsection{Dibidang Ekonomi Kerakyatan}

Dalam rangka meningkatkan kesejahteraan masyarakat, pemerintah daerah membuat program zero kemiskinan, zero pengangguran, zero rumah kumuh, untuk mengimplementasikan itu pemerintah daerah membuat Pusat Pelatihan Pertanian dan Pedesaan swadaya (P4S) berlokasi di kubang, Kecamatan Siak Hulu Kabupaten Kampar, telah dididik masyarakat daerah terpencil dan penduduk miskin pada daerah tersebut telah mampu diberdayakan untuk mandiri dalam menghasilkan pendapatan melalui pertanian misalnya membuat kebun cabe, perternakan dengan beternak kerbau atau sapi, tidak saja diberi pelatihan tetapi juga diberikan kemudahan dalam menjalankan usaha dengan pemberian pinjaman melalui bank, dengan bunga yang rendah. Bank yang dimaksud adalah bank yang memiliki kerjasama dengan pemerintahan darah. Selain meningkatkan kesejahteraan secara otomatis mengurangi penganggguran di masyarakat karena masyarkat memiliki peluang untuk usaha. Dalam pengentasan rumah kumuh pemerintah daerah telah secara teliti mensurvei dan melaksanakan pembangunan rumah masyarakat yang dianggap layak untuk diberikan bantuan berupa pembangunan rumah. Adapun sasaran dalam bidang ini adalah :

1. Meningkatnya Pertumbuhan Ekonomi Daerah Dan Pemerataan Pendapatan, sasaran ini menggunakan 12 indikator kinerja yaitu pendapatan perkapita regional, PDRB atas dasar harga yang berlaku,PDRB atas dasar konstan, penerimaan daerah, pertumbuhan investasi, inflasi, peningkatan SDM BUMD, peningkatan SDM dalam lembaga keuangan mikro, fasilitasi peran masyarakat dalam pemanfaatan ruang, fasilitasi dalam kerjasama investasi, kajian kebijakan dalam pemberian insentif, pembentukan kekuatan kerjasama. Rata-rata pencapaian tidak mencapai $50 \%$ hanya $33.61 \%$, hal ini disebabkan masih rendanhya pertumbuhan investasi dan hanya 3 indikator ynag diatas $100 \%$ yaitu indkator.sedangkan 6 indikator belum bisa diukur karena data tidak memadai dalam melakukan pengukuran.

2. Meningkatnya Peran Lembaga Keuangan Mikro Dipedesaan, sasaran ini diukur dengan menggunakan 10 indikator kinerja yaitu fasilitasi dan koordinasi kerjasama, jumlah lembaga keuangan mikro, jumlah lembaga keuangan makro, jumlah 
koperasi aktif, jumlah UKM non BPR, jumlah UKM BPR, rata-rata kelompok binaan LPM,LPM berprestasi,swadaya masyarakat atas program pemberdayaan masyarakat,pemeliharaan pasca program pemberdayaan. Hasil kinerja menunjukkan $32.11 \%$, karena masih byk indicator kinerja yang tidak bisa diukur karena ketidaktersediaan data.

3. Meningkatnya Pendapatan Asli Daerah Kabupaten Kampar. Indikator yang digunakan sejumlah 2 indikator yaitujumlah dan macam pajak daerah,jumlah dan macam retribusi daerah, dengan rata-rata pencapaian kinerja 88,64\% hal ini disebabkan oleh jumlah rettibusi daerah belum mencapai $100 \%$ dari target yang telah ditetapkan.

4. Meningkatnya Sumber Pendapatan Asli Daerah Berdasarkan Pola Ruang, sasaran ini menggunakan 10 indikator kinerja yaitu :peningkatan kontribusi PAD dari sector pajak, peningkatan PAD dari retribusi jasa umum, peningkatan PAD dari retribusi jasa khusus,peningkatan PAD dari sector jasa perizinan,hasil pengelolaan kekayaan daerah yang dipisahkan,penerimaan jasa giro, pendapatan dari penjualan cicilan,lainlain PAD yang sah. Rata-rata pencapaian kinerja pada sasaran ini hanya $74.46 \%$ hal ini dikarenakan masih adanya indicator yag masih $23.35 \%$ pencapaian kinerja yaitu indiakator pengambilan pajak galian $\mathrm{C}$, dan retribusi pelayanan persampahan yang hanya $38.83 \%$. sehingga disarankan mestinya daerah memaksimalkan pengambilan pajak untuk ke 2 indikator ini, sehingga baik pajak maupun retribusi bisa dimaksimalkan.

5. Meningkatnya Investasi Swasta menggunakan 10 indikator kinerja yaitu pertumbuhan investasi,penanaman modal asing dan penanaman modal dalam negri, jumlah nilai investasi berskala nasional PMA, jumlah nilai investasi berskala nasional PMDN, rasio daya serap tenaga kerja PMDN, rasio tenaga kerja PMA,kenaikan dan penurunan nilai realisasi PMDN,jumlah UMKM yang mengikuti pemeran. Dalam LAKIP tahun 2013 disebutkan 10 indikator, namun yang indicator yang ada hanya 8 indikator kinerja dan masih banyaknya indicator yang belum bisa dinilai karena tidak bisa diukur dengan alasan belum terkumpulnya data. Padahal seharusnya alasan ini tidak ada, ini menunjukkan bahwa daerah tidak mampu mengukur dengan baik dan tidak memiki data untuk dipertanggungjawabkan kepada masyarakat, sehingga realisasi rata-rata capaian kinerja hanya $51.37 \%$. sedangkan indicator untuk daya serap tenaga kerja menunjukan rasio diatas $100 \%$.

6. Menurunnya Tingkat Pengangguran, dalam LAKIP Kab.Kampar indicator yang digunakan adalah 35 indikator, yang capaian rata-rata kinerja adalah $74.17 \%$. 13 indikator kinerja tidak bisa diukur karena tidak mencukupi data yang ada.

\subsection{Dibidang Peningkatan Infrastruktur}

Berkenaan dengan infratruktur dapat dilihat dari banyaknya jalan yang dibangun baik di daerah pedesaan dan daerah perkotaan, semakin banyknya daerah yang kini mampu dilewati oleh kendraan roda empat. Pembangunan jembatan menghubungkan 2 desa sehingga semakin memperlancar arus informasi dan transfportasi.

\subsection{Dibidang Keuangan}

Dari tahun ketahun mengalami peningkatan yang signifikan, pada tahun 2012 APDB Kampar Rp 1.929.185.864.973,37 dan pada tahun 2013 APBD kabupaten Kampar Rp 2.449.722.769.487,00 dan yang terealisasi sebesar Rp 2.118.672.305.620,00 sekitar $86.49 \%$. 


\section{KESIMPULAN}

Pemerintah Daerah adalah penyelenggaraan pemerintahan di daerah. Dengan kata lain, Pemerintah Daerah adalah pemegang kemudi dalam pelaksanaan kegiatan pemerintahan daerah, Karena pemerintah daerah adalah yang memegang kemudi didalan pelaksanaan kegiatan daerah, maka pemerintah daerah sebagai pelaksana harus memahami apa yang dibutuhkan oleh masyarakat, memastikan bahwa setiap pelayanan public yang diberikan adalah pelayanan yang layak, memastikan bahwa setiap anggota masyarakat mendapatkan pelayanan kesehatan yang merata diseluruh daerah, dan mengusahakan akan kenyamanan dan keamanan bagi masyarakat daerah. Dengan diberlakukannya otonomi daerah membuat daerah lebih bertanggungjawab terhadap apa yang dilakukan demi terciptanya visi misi daerah. Salah satu keberhasilan daerah dapat dilihat dari sebserapa besar pemerintah daerah memilki kinerja yang baik dalam melaksanakanya pemerintahan, yang dilihat dari beberapa bidang yaitu bidang agama, kesehatan, infrastruktur, pendidikan, keuangan ekonomi kerakyatan. Dan hal-hal ini dipertanggungjwabkan daerah kepada publik dengan membuat Laporan Kinerja Pemerintah. Dari LAKIP yang dibuat dapat dilihat masih adanya kekurangan-kekurangan dalam mengukur indicator kinerja, masih terdapatnya indicator knerja yang masih belum bisa diukur dengan alasan tidak adanya data yang memadai untuk pertanggungjawaban, masih adanya beberapa bidang yang memilki pencapaian kinerja tidak mencapai $100 \%$.

\section{DAFTAR PUSTAKA}

Astri, W.W., 2009. Laporan Akuntabilitas Kinerja Pemerintah (LAKIP). http://gitacintanyawilis.blogspot.com/ 2009/11/laporan-akuntabilitaskinerja diakses pada Oktober 2010

Laporan Kinerja Pemerintah Daerah Kabupaten Kampar.2013.

Republik Indonesia. Undang-Undang Republik Indonesia No. 22 tahun 2003 tentang Susunan dan Kedudukan MPR, DPR, DPD dan DPRD. Citra Umbara, Bandung

Undang-Undang Republik Indonesia No. 22 tahun 1999 tentang Pemerintahan Daerah. Citra Umbara, Bandung

Undang-Undang

Republik Indonesia No. 25 tahun 1999 tentang Perimbangan Keuangan antara Pemerintah Pusat dan Daerah. Citra Umbara, Bandung.

Undang-Undang Republik Indonesia No. 32 tahun 2004 tentang Pemerintahan Daerah. Depertemen Dalam Negeri Republik Indonesia.

Undang-Undang Republik Indonesia No. 33 tahun 2004 tentang Perimbangan Keuangan antara Pemerintah Pusat dan Daerah. Depertemen Dalam Negeri Republik Indonesia.

No. 105 tahun 2000 tentang Pengelolaan dan Pertanggungjawaban Keuangan daerah. Depertemen Dalam Negeri Republik Indonesia.

Keputusan Presiden No. 74 tahun 2001 tentang Tata Cara Pengawasan Penyelenggaraan Pemerintah Daerah. Depertemen Dalam NegeriRepublik Indonesia. 